J. Dairy Sci. 97:6693-6699

http://dx.doi.org/10.3168/jds.2014-7990

() American Dairy Science Association ${ }^{\circledR}, 2014$. Open access under CC BY-NC-ND license.

\title{
Sensory analysis and species-specific PCR detect bovine milk adulteration of frescal (fresh) goat cheese
}

\author{
L. P. Golinelli, ${ }^{*}$ A. C. Carvalho,† R. S. Casaes, ${ }^{*}$ C. S. C. Lopes, ${ }^{*}$ R. Deliza, $¥$ V. M. F. Paschoalin, ${ }^{* 1}$ \\ and J. T. Silva* \\ *Instituto de Química, Universidade Federal do Rio de Janeiro, Av. Athos da Silveira Ramos 149 Cidade Universitária 21949-909, Rio de Janeiro, \\ RJ, Brazil \\ †Faculdade de Farmácia, Universidade Federal do Rio de Janeiro, Av. do Aloízio, 50 - Granja dos Cavaleiros, Macaé 27930-560, Rio de Janeiro, \\ RJ, Brazil \\ †Embrapa Agroindústria de Alimentos, Av. das Américas 29501 23020-470, Rio de Janeiro, RJ, Brazil
}

\begin{abstract}
The Brazilian market for dairy products made from goat milk is increasing despite the seasonality of production and naturally small milk production per animal, factors that result in high-priced products and encourage fraud. In Brazil, no official analytical method exists for detecting adulteration of goat dairy products with cow milk. The aim of this study was to design a strategy to investigate the adulteration of frescal (fresh) goat cheeses available in the Rio de Janeiro retail market, combining analysis of cheese composition and the perception of adulteration by consumers. Commercial goat cheeses were tested by using a duplex PCR assay previously designed to authenticate cheeses, by targeting the mitochondrial $12 \mathrm{~S}$ ribosomal RNA genes of both species simultaneously. The PCR test was able to detect $0.5 \%$ ( vol/vol) cow milk added during goat cheese formulation. The analysis of 20 locally produced goat cheeses (20 lots of 4 brands) showed that all were adulterated with cow milk, even though the labels did not indicate the addition of cow milk. To estimate the ability of consumers to perceive the fraudulent addition of cow milk, a triangle test was performed, in which cheeses formulated with several different proportions of goat and cow milk were offered to 102 regular consumers of cheese. Detection threshold analysis indicated that almost half of the consumers were able to perceive adulteration at $10 \%$ ( vol/vol) cow milk. Effective actions must be implemented to regulate the market for goat dairy products in Brazil, considering the rights and choices of consumers with respect to their particular requirements for diet and health, preference, and cost.
\end{abstract}

Received January 28, 2014.

Accepted July 13, 2014.

${ }^{1}$ Corresponding author: paschv@iq.ufrj.br
Key words: frescal (fresh) goat cheese, bovine and caprine species-specific PCR, mitochondrial DNA, consumer detection threshold

\section{INTRODUCTION}

Raising dairy goats is becoming established as a profitable activity in Brazil, following the regulation of its commerce by the Brazilian Ministry of Agriculture, Livestock and Food Supply (MAPA). In 2000, MAPA established, through its normative instruction No. 37 (Brazil, 2000), the conditions for production, identity, and minimum requirements of goat milk, as well as criteria for pasteurization and sterilization of the final product. The annual production of goat milk in Brazil is around 148,149 $\mathrm{t}$ (FAOSTAT, 2011), 90\% of which is produced in northeastern Brazil.

Goat milk is a complete food, rich in proteins, vitamins, minerals, and small fat molecules, which makes it highly digestible compared with milk from other animal species. These nutritional features have contributed to the growth of the market for goat dairy products, and consequently have attracted the interest of farmers in different regions of the country.

Goat milk is considered a good alternative to human and cow milk for various clinical conditions such as allergy, atopy, and inflammatory diseases (Jirillo et al., 2010). The major proteins from cow milk are $\alpha_{\mathrm{S}^{-}}$casein and $\alpha$-lactalbumin, whereas the major protein fraction of goat milk is composed of $\beta$-casein, $\alpha_{\mathrm{S}_{2}}$-casein, and a small amount of $\alpha_{\mathrm{S1}^{-}}$-casein (Fisberg et al., 1999). Cow milk allergy is a common condition, affecting $5.7 \%$ of Brazilian children (Binsfeld et al., 2009) during the first $3 \mathrm{yr}$ of life and 12 to $30 \%$ of infants less than 3 mo old, with frequencies as high as $20 \%$ in certain areas. The substitution of goat milk for cow milk is reported to resolve between 30 and $40 \%$ of problem cases (Haenlein, 2004).

In spite of the nutritional advantages, the market for goat milk and its derivatives in Brazil is not yet fully 
developed. The challenges to the Brazilian goat dairy industry result from several factors, ranging from the manufacturing process of the milk itself to problems related to the acceptance of goat dairy products. One of the problems is the "goaty" smell of the milk and milk products, which can be corrected on the farms by isolating the buck during the milking process (Carunchia Whetstine et al., 2003). Factors that might influence the characteristic flavor are the high concentration of FFA, especially the short-chain FA (C6 to C10), the $\mathrm{KCl}$ concentration, and the presence of some cresols (ortho-, meta-, and para-cresols; Skjevdal, 1979). Morgan and Gaborit (2001) reported that cold storage of the milk increased the goaty flavor, whereas heat treatment resulted in a slight reduction. Another issue is the higher cost of these dairy products compared with cow milk products, due to the smaller size of goats and the irregular milk production during the dry season on Brazilian goat farms. As mentioned above, dairy goat businesses are not yet fully established in Brazil, and there are no regulations or guidance on the evaluation of goat products that could prevent mischaracterization of the final product. This lack of regulation has led to fraudulent practices, such as mixing different concentrations of cow and goat milks to reduce costs and, at the same time, reduce the strong aroma of goat milk and add volume to the finished product.

Several analytical methods have been developed to discriminate mixtures of milks from different ruminant species. Most of these methodologies are based on the protein profile of the milk sample (Egito et al., 2006), and are usually accomplished by immunological (Addeo et al., 1995), electrophoretic (Cartoni et al., 1998), or chromatographic assays such as reversed phase-HPLC or fast protein liquid chromatography, which are used to separate the casein profiles of bovine, ovine, or caprine milks (Law and Tziboula, 1992; Kaminarides and Anifantakis, 1993). Recently, PCR-based methods were designed and applied to dairy products to authenticate cheeses, and these methods can detect very small amounts of cow milk in goat cheese (Bottero et al., 2003) or in Mozzarella cheese made from Asian buffalo milk (Feligini et al., 2005). Mašková and Paulíčková (2006) used the PCR method to detect cow milk in goat and sheep cheeses.

Although several analytical methodologies can efficiently detect adulteration in goat dairy products, none are currently being used as reference methods by Brazilian regulatory agencies to detect adulteration or mislabeling of these products. It is also important to determine the point (i.e., the degree of adulteration) at which consumers of goat cheese could detect that a cheese product contains cow milk. To date, few studies have focused on both the analytical and sensory as- pects. Therefore, it is important to investigate whether the Brazilian consumer would be able to detect adulteration in goat products, taking into account that this is not yet a well-established market in Brazil.

Among the methods used for sensory evaluation of food products, the triangle test is widely used as a discriminative method that indicates whether a noticeable difference exists between 2 samples; that is, it can determine whether adulteration of a food product could be perceived by consumers (Meilgaard et al., 1991). The unequivocal molecular species-specific PCR was combined with a sensory evaluation, to determine if the adulteration of goat cheeses could be perceived by consumers.

\section{MATERIALS AND METHODS}

\section{Experimental Materials}

Blood samples from 10 cows (Girolando breed) and 10 goats (Saanen breed) were collected in BD Vacutainer tubes containing heparin (Materiais and Acessórios Médicos, Anhui, China) and were stored in insulated containers. Blood from each species was pooled, and DNA templates were prepared and used as PCR control samples for species-specific identification.

Twenty goat cheeses from 4 different brands were purchased in the stores of 3 supermarket chains in the Rio de Janeiro metropolitan area, over a 12 -mo period in from 2010 to 2011, according to the seasonality of goat milk and therefore the availability of the cheeses in the market. The samples were distributed as follows: 7 different batches each of brands I and II and 3 batches each of brands III and IV (these last 2 brands were not available during the entire sampling period).

Samples of $100 \mathrm{mg}$ from each commercial goat cheese were collected for DNA extraction and individually macerated in a porcelain crucible. DNA templates from the cheeses and from blood of cows and goats were prepared by using the DNeasy Blood and Tissue Kit (Qiagen, Valencia, CA). The DNA was quantified by using a Qubit fluorometer (Invitrogen Life Technologies, Eugene, OR).

\section{PCR Duplex}

Pairs of primers targeting 12S rRNA were selected from those proposed by Bottero et al. (2003) and synthesized by Invitrogen Life Technologies. The primer pair to detect Capra hircus (forward: 5'-CGCCCTCCAAATCAATAAG-3' and reverse 5'-AG TGTATCAGCTGCAGTA GGGTT-3') (GenBank accession number M55541) and the primer pair to detect Bos taurus (forward 5'-GTACTACTAGCAACAGCTTA-3' 
and reverse 5'-GCTTGATTCTCTTGG TGA-3' (GenBank accession number NC001567) produced amplicons of 326 and $256 \mathrm{bp}$, respectively. Pairwise nucleotide sequences were aligned for similarity searching in BLASTn (Altschul et al., 1990) at the National Center for Biotechnology Information (http://www.ncbi.nlm. nih.gov/blast/Blast.cgi). Primer sequences were aligned with the bovine and caprine sequences available in the GenBank database.

To detect each animal species simultaneously, the primer sets were used in a one-step reaction: amplifications were carried out in a final volume of $50 \mu \mathrm{L}$ containing $10 \mathrm{~m} M$ Tris- $\mathrm{HCl}$ (pH 8.3), $2 \mathrm{U}$ of AmpliTaq Gold DNA polymerase (PE Applied Biosystems, Foster City, CA), $0.2 \mathrm{mM}$ of each deoxynucleotide triphosphate, $2.5 \mathrm{mM} \mathrm{MgCl} 2,25$ and $30 \mathrm{pmol}$ of each set of primers, and $250 \mathrm{ng}$ of each DNA template. After an initial denaturation step at $94^{\circ} \mathrm{C}$ for 5 min, 35 cycles were programmed as follows: $94^{\circ} \mathrm{C}$ for $30 \mathrm{~s}, 55^{\circ} \mathrm{C}$ for $1 \mathrm{~min}, 72^{\circ} \mathrm{C}$ for $1 \mathrm{~min}$, and final extension at $72^{\circ} \mathrm{C}$ for 5 min. Amplified fragments were resolved on a 1.5\% agarose electrophoresis gel run in Tris acetate EDTA buffer (40 $\mathrm{m} M$ Tris-acetate; $1 \mathrm{~m} M$ EDTA) for $70 \mathrm{~min}$ at $120 \mathrm{~V}$. Gels were stained with GelRed (Biotium, Hayward, CA) in $45 \mathrm{~mL}$ of distilled water for $30 \mathrm{~min}$ under stirring and constant light, and were documented under UV light (DNR Bio-Imaging Systems, MiniBis Pro, Hamisha, Israel).

To establish the detection threshold (DT) of cow milk addition in goat cheeses, cheeses were made with mixtures of cow and goat milk in different proportions: $0.1,0.5,1,10,25$, and $40 \%$ (vol/vol). The DNA extraction was run in duplicate from each mixture and used as a template for duplex PCR targeting the $12 \mathrm{~S}$ rDNA as described above.

\section{Cheese Processing Using Goat and Cow Milk Mixtures}

To define cheese formulation, a preliminary sensory test of consumers' perception of adulteration was performed using goat and cow milk in different proportions: 0:100, 5:95, 10:90, 15:85, 25:75, 50:50, and 75:25 cow:goat milk (vol/vol). The mixture formulated with $100 \%$ goat milk (control sample) was used as the reference in the sensory evaluation. Ten subjects were recruited as sensory panelists, and the mixtures were offered randomly. The panelists were able to perceive adulteration in the mixtures that contained $25 \%$ or more added cow milk.

Raw goat and cow milks were pasteurized and used to produce frescal ("fresh") cheeses at several cow:goat ratios $(0: 100,10: 90,25: 75,40: 60,55: 45$, and 70:30). The cheese formulated with $100 \%$ goat milk was used as a reference in the sensory evaluation. The cheeses were manufactured according to the standard procedures of Monteiro et al. (2011). The batches were produced randomly on $2 \mathrm{~d}$, using the same batch of pasteurized milk. We observed no visual difference in appearance (color) among cheeses produced with different ratios of cow and goat milk. To analyze the microbiological quality of the cheeses, those formulated with 0:100 and 50:50 cow:goat milks were evaluated for the presence of Salmonella spp. and Listeria monocytogenes, coliform counts at $45^{\circ} \mathrm{C}$, and counts of coagulase-positive Staphylococcus, according to Brazilian legislation (Brazil, 2006).

\section{Detection Threshold Procedure}

Regular consumers of frescal cheese (at least once per week) were recruited from among the staff members and students from Embrapa Food Technology (Rio de Janeiro, Brazil). One hundred two subjects were recruited as sensory panelists for a series of triangle tests, divided into 2 sessions, to determine the DT for the addition of cow milk to goat cheese. Forty-four women and 58 men aged between 18 and 65 yr took part in the study. Fifty-eight percent of them were between 18 and $35 \mathrm{yr}$ of age, and $89 \%$ had completed high school or were in university-level courses. Thirty-five percent declared a monthly income from 1 to 5 times minimum wage (local Brazilian salary), and only $37 \%$ had children living at home. Thirty-three percent of the subjects consumed frescal cheese more than once a week. Only $17 \%$ of consumers had tried goat cheese before this study; the reasons given were to try a variety of foods (5\%), decrease allergic reactions (3\%), nutrient composition $(3 \%)$, and taste $(2 \%)$. The study protocol was submitted to an Ethics Committee for approval, and all panelists signed a consent form. The participants were familiar with basic sensory evaluation techniques.

Cheese samples were removed from the refrigerator, cut into small cubes (about $10 \mathrm{~g}$ each), and placed on white plates coded with random 3 -digit numbers. Cheese cubes from the 3 replications of the same batch were mixed randomly so that all replications from the same batch were presented an equal number of times. Then, DT were measured using a series of triangle tests in which 1 of the 3 samples contained a certain percentage of cow milk in the goat cheese $(10,25,40$, 55 , or $70 \%$ cow milk), using $100 \%$ goat milk as the reference sample, as described above. Cheese consumers were asked to identify the different samples. Cheeses made with different proportions of cow and goat milk were presented in random order to each panelist, and the position of the adulterated sample within each test was randomized across each series. The tests were 
conducted on 2 consecutive days. Water and unsalted crackers were provided to refresh the participants' palates. Significant differences were determined using the method of Roessler et al. (1978).

\section{RESULTS AND DISCUSSION}

\section{Analysis of Commercial Cheese Composition by Duplex PCR}

The duplex PCR assay was optimized for discriminating cow milk in goat cheese matrices to detect adulteration of cheese with cow milk. The PCR tests used in this screening were very sensitive, specific, and reproducible. Duplex PCR tests showed a minimum detection limit of $0.5 \%(\mathrm{vol} / \mathrm{vol})$, indicating that the analytical assay unequivocally detected cow milk, even when it was present in small amounts (Figure 1). The detection limit is very similar to that described by Bottero et al. (2003) and Feligini et al. (2005). Other authors detected amounts of cow milk as low as $1 \%$ (Mašková and Paulíčková, 2006) and 0.1\% (LópezCalleja et al., 2005; Mafra et al., 2007). Although the PCR tests optimized in this study were able to detect amounts as small as $0.5 \%$ cow milk, it should be noted that amounts $\leq 1.0 \%$ of cow milk may well arise from involuntary cross-contamination during cheese manufacturing, if the dairy plant is not exclusively dedicated to goat cheese manufacture, or during the collection of milk from several farms that also produce cow milk (Mašková and Paulíčková, 2006).

Twenty samples from commercial goat cheeses purchased in the Rio de Janeiro retail market were analyzed by the duplex PCR tests. In all of them, the PCR assays amplified the 256-bp fragment expected for cow

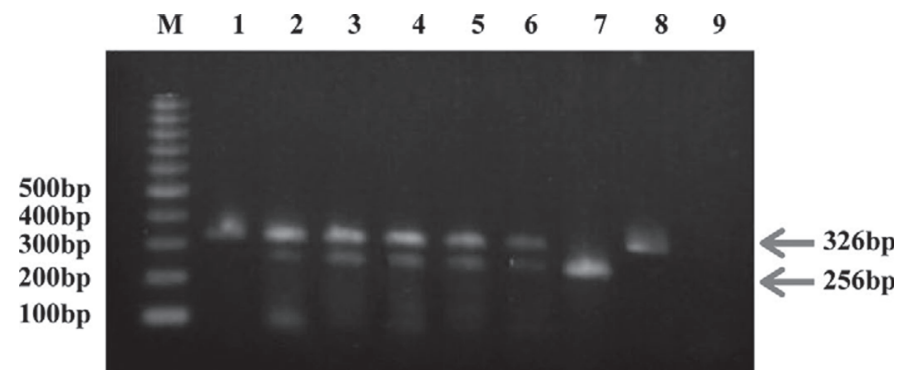

Figure 1. Determination of detection limit of cow milk adulteration in goat cheese. Cheeses were made from different concentrations of cow milk added to goat milk. DNA was extracted from each mixture and used as a template for amplification by duplex PCR targeting 12S rRNA. The band at $256 \mathrm{bp}$ was diagnostic for cow milk and that at 326 bp was diagnostic for goat milk. $\mathrm{M}=100$-bp ladder; lanes 1 to $6=$ cow:goat mixtures at $0.1,0.5,1,10,25$, and $40 \%$ (vol/vol); lanes 7 and $8=$ blood samples from cow and goat, respectively; lane $9=$ control reagents. Samples were run in duplicate. derived-material, in addition to the 326-bp amplicon from goat. The former fragment indicates the addition of cow milk, considered an adulterant component, in all commercial samples sold as frescal goat cheeses available in the retail market in the metropolitan area of Rio de Janeiro (Figure 2A and 2B). Brazilian regulation defines adulteration as the presence of substances of any quality, type, and species different from those of the normal composition of the product, without prior authorization from the Department of Inspection of Animal Products (Brazil, 1952). Fraudulent mislabeling not only misleads the consumer, but it can also be harmful to health, especially in individuals who are allergic to cow milk protein and must use goat milk as a substitute. Although it is not a problem in mature markets such as those in North America or Europe, this issue is of great importance in Brazil and perhaps in other countries. The PCR test optimized in this study conferred the molecular basis for mapping the goat cheeses marketed in the state of Rio de Janeiro, and could be very useful for food agencies to regulate dairy products and as a legal tool to protect consumers.

Some regional retailers of dairy products of caprine origin have declared that the addition of cow milk to goat milk and derivatives improves the acceptability of these products in the consumer market. According to Regulamento da Inspeção Industrial e Sanitária de Produtos de Origem Animal (Brazil, 1952), the term "milk," if not otherwise specified, means the product derived from the complete, uninterrupted milking of well fed and rested healthy cows. The milk of other livestock should be named according to the species that produced it and must be clearly specified on the label of the product.

This study did not include a quantitative analysis for DNA adulteration of goat cheeses. As adulteration is prohibited under the current legislation regulating dairy products in Brazil, the PCR assay was a qualitative test for the presence or absence of adulterant milk.

\section{Threshold of Detection of Cow Milk in Goat Cheese by Consumers}

One of the major difficulties in the dairy market in Brazil is the seasonality of goat milk production, which is the reason for the 2.5-fold difference, on average, in the price of goat milk and cow milk (FarmPoint, 2013). To be economically significant, fraudulent addition of cow milk would need to be more than $10 \%$.

To test consumer perception of cheese composition, formulations were prepared using mixtures with more than $10 \%$ (vol/vol) cow milk, although in a preliminary sensory test the consumers did not perceive adulteration levels less than $25 \%$ ( $\mathrm{vol} / \mathrm{vol})$. 

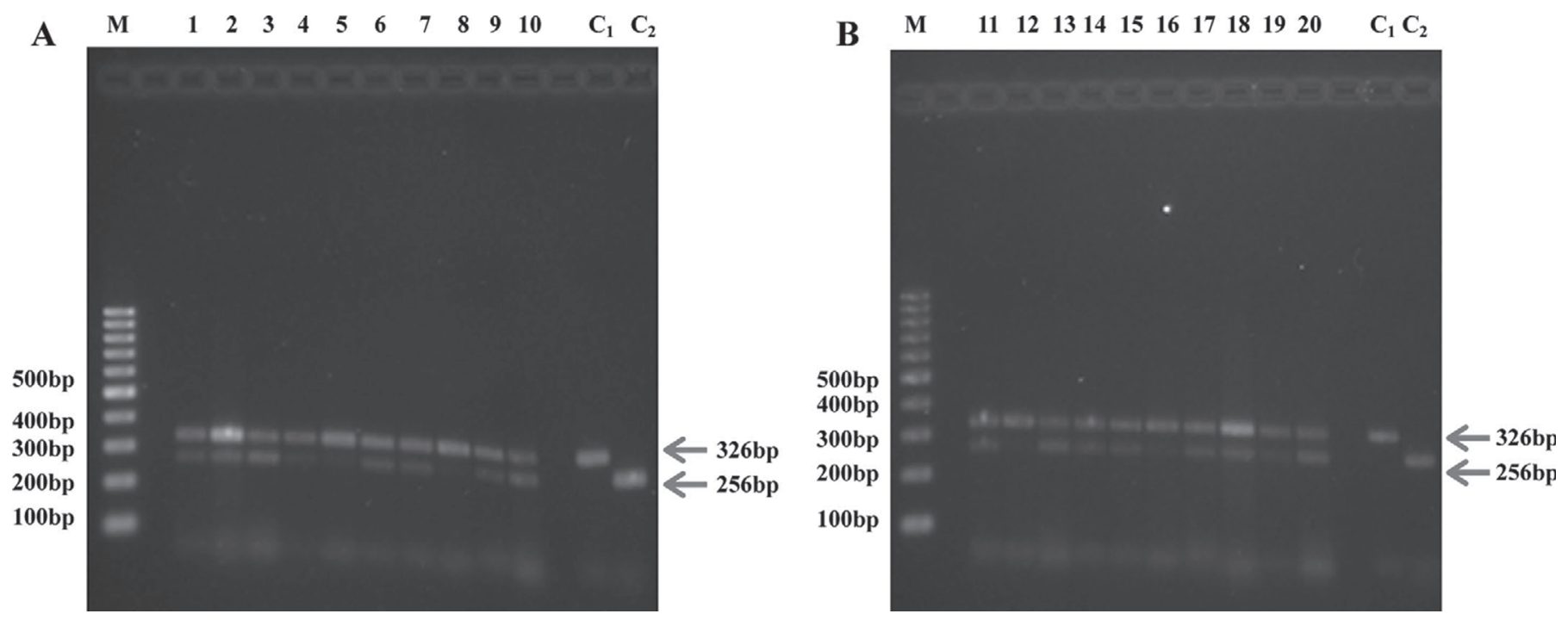

Figure 2. Detection of adulteration of goat cheese with cow milk by amplification of goat and cow $12 \mathrm{~S}$ mitochondrial rRNA gene sequences by duplex PCR tests using DNA templates obtained from samples of goat cheeses available in the retail market in the Rio de Janeiro metropolitan area. (A) $\mathrm{M}=100$-bp DNA ladder; lanes $1-7=$ different lots of brand I of goat cheese; lanes $8-10=$ different lots of brand II; $\mathrm{C}_{1}$ and $\mathrm{C}_{2}=$ blood samples from goat and sheep, respectively. (B) $\mathrm{M}=100$-bp DNA ladder; lanes 11-14 = different lots of brand II; lanes $15-17=$ different lots of brand III; lanes 18-20 = different lots of brand IV; $\mathrm{C}_{1}$ and $\mathrm{C}_{2}=$ blood samples from goat and cow, respectively. Samples were run in duplicate.

Raw goat and cow milks were pasteurized and used to produce frescal cheeses at the following cow-to-goat ratios: 0:100, 10:90, 25:75, 40:60, 55:45, and 70:30. The frescal cheeses were analyzed by PCR, which correctly identified the presence of milk from goats and cows in the formulations. A microbiological analysis of the frescal cheeses produced showed that samples were safe for consumption by the panelists who participated in the study, as they met the standards set by Brazilian legislation.

Forty-six panelists identified the different sample when the reference sample was compared with the cheese with $10 \%$ added cow milk; 56 subjects were able to choose the different sample when the reference was assessed against a sample with $25 \%$ cow milk; 43 consumers made the correct judgment when cheese with $40 \%$ cow milk was tested against the reference. Finally, 67 and 62 individuals chose the correct sample when cheeses with 55 and $70 \%$ cow milk, respectively, were tested against the reference cheese ( $100 \%$ goat cheese). All proportions of added cow milk, even the lowest amount of $10 \%$, were identified by participants in this study, because significant results were obtained in the triangle tests (Roessler et al., 1978), considering that a minimum number of 43 trials was required to establish significance $(P<0.5, \mathrm{n}=102)$.

Figure 3 shows the proportions of consumers who correctly identified the different sample in the triangle tests. The solid line (0.33) represents a chance response, and the dotted line indicates the $5 \%$ significance cri- terion (0.43) using the binomial distribution for the triangle test $(\mathrm{n}=102)$. The DT is the magnitude of change in the stimulus needed to produce a perceived difference. The number of correct answers increased with increasing proportions of cow milk, except for $40 \%$ cow milk. As expected, higher proportions of correct answers occurred for the cheeses containing 55 and $70 \%$ cow milk, indicating that it was easier to differentiate higher proportions of cow milk against the reference (100\% goat milk). Taking into account the comments made by the panelists about the samples, approximately $50 \%$ agreed in saying that 55 and $70 \%$ cow milk in the cheese made the products "tastier" and "more palatable." Further comments by the participants for the 3 lowest percentages $(10,25$, and $40 \%$ cow milk) referred to "bitter," "salty," and "strong" products.

Santos et al. (2011) evaluated consumer acceptance of curd cheese formulated with goat and cow milks in different proportions of $0,15,30,45$, and $60 \%$ goat milk, and observed that the cheeses that received the lowest scores for flavor were those containing higher percentages of goat milk ( 45 and $60 \%$ goat milk), in agreement with the results reported by Queiroga et al. (2009). This may have occurred because the frescal cheese formulated with the highest percentage of cow milk is more similar in flavor to the Minas Frescal cheese that is widely consumed in the Rio de Janeiro metropolitan area, and perhaps also because of the slightly higher percentage of fat. Although adulteration of frescal goat cheeses is fraudulent, the Brazilian consumer may still be less 


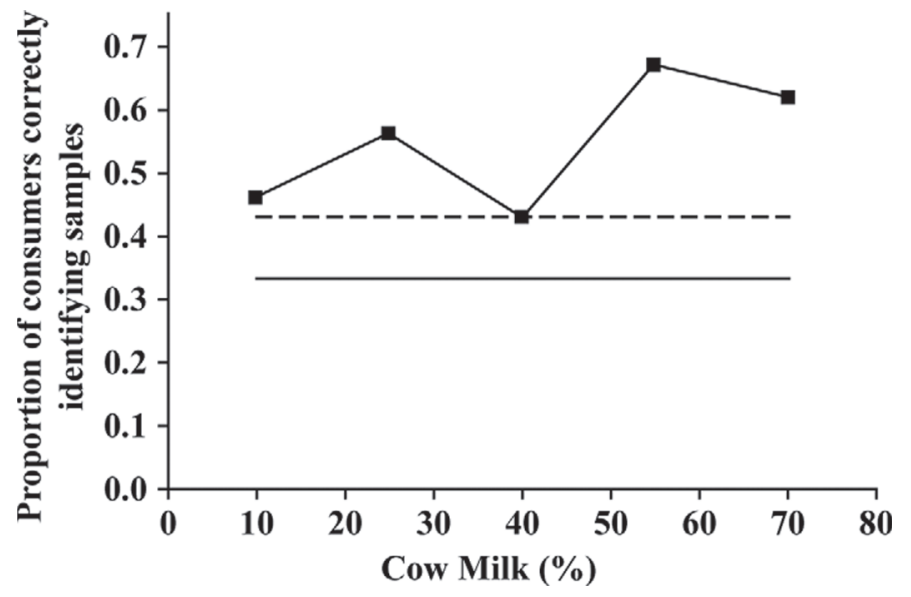

Figure 3. Proportion of panelists identifying the cheese with added cow milk in the triangle test. The solid line $(0.33)$ represents the chance response, and the dotted line indicates the 5\% significance criterion (0.43), using the binomial distribution for the triangle tests $(\mathrm{n}=102)$.

accustomed to consuming dairy goat products than consumers in the European, North American, or Asian markets. On the other hand, even consumers inexperienced with goat cheese were able to identify the sample with added cow milk, suggesting that producers should be aware that even minimal alteration can be perceived by consumers, and may affect consumer preference for certain brands. Products with a high fat concentration are better accepted by consumers and thus are easier to differentiate. Goat milk fat contains significant levels of 4-methyloctanoic and 4-ethyloctanoic acids; the former is present only in low levels in bovine milk, whereas the latter is absent (Ha and Lindsay, 1991). Because of these characteristics, goat milk has a strong odor and flavor, which according to Park et al. (2007) is one of the obstacles in marketing these products, which thus creates an opportunity for adulteration. According to this point of view, the adulterated product will be more readily accepted by Brazilian consumers. Further studies focusing on consumer acceptance in different areas of the country are required, and marketing strategies are needed to encourage consumption of this product, as it has considerable nutritional value. Furthermore, the popularization of goat cheese production would benefit small farmers in Brazil who produce goat milk. Alternatively, the market could be opened to a more sophisticated consumer of dairy products, who is interested in novelty and new flavors.

\section{CONCLUSIONS}

In this study, a reliable, sensitive, and species-specific PCR test was used for screening the presence of cow milk in locally produced frescal (fresh) goat cheeses sold in the retail market in Rio de Janeiro. All commercial samples of frescal goat cheeses assessed by duplex PCR identified cow milk (the adulterant component) in the goat cheese matrices, indicating that $100 \%$ of the goat cheeses produced and marketed in the largest metropolitan area of Rio de Janeiro had undergone tampering. The duplex PCR assay described here is suitable for routine testing of cheese matrices or the milk before cheese processing in dairy plants, to protect manufacturers and consumers from fraudulent practices. The ability of consumers to identify goat cheese adulteration was assessed by a triangle-test sensory analysis. The DT (of adulteration) could not be determined from this study, because even the smallest percentage of cow milk added to goat cheese was perceived by consumers.

\section{ACKNOWLEDGMENTS}

This paper is dedicated to the memory of J. T. Silva, with gratitude for his guidance, friendship, and dedication during the investigation. We acknowledge CAPES (Coordenação de Aperfeiçoamento de Pessoal de Nível Superior, Rio de Janeiro, Brazil) for the award of a fellowship to Luciana Golinelli, and FAPERJ (Fundação de Amparo à Pesquisa do Estado do Rio de Janeiro, Rio de Janeiro, Brazil) for financial support. The authors thank members of NATA (Núcleo Avançado em Tecnologia de Alimentos, Rio de Janeiro, Brazil), a public technical high school, for the use of the facilities of the industrial dairy plant to produce the frescal cheeses used to determine the detection threshold for cow's milk adulteration.

\section{REFERENCES}

Addeo, F., M. A. Nicolai, L. Chianese, L. Moio, S. Spagna Musso, A. Bocca, and L. Del Giovine. 1995. A control method to detect bovine milk in ewe and water buffalo cheese using immunoblotting. Milchwissenschaft 50:83-85.

Altschul, S. F., W. Gish, W. Miller, E. W. Myers, and D. J. Lipman. 1990. Basic local alignment search tool. J. Mol. Biol. 215:403-410.

Binsfeld, B. L., A. C. Pastorino, A. P. B. M. Castro, G. H. Yonamine, A. K. F. Gushken, and C. M. A. Jacob. 2009. Knowledge of industrialized dairy product labels by parents of patients allergic to cow's milk. Revista Paulista de Pediatria 27:296-302.

Bottero, M. T., T. Civera, D. Nucera, S. Rosati, P. Sacchi, and R. M. Turi. 2003. Multiplex polymerase chain reaction for the identification of cows', goats' and sheep's milk in dairy products. Int. Dairy J. $13: 277-282$.

Brazil. 1952. Regulamento da Inspeção Industrial e Sanitária de Produtos de Origem Animal (RIISPOA). Decreto $\mathrm{n}^{\mathrm{O}}$ 30.691, de 29 de março de 1952. Ministério da Agricultura, Pecuária e Abastecimento, Brasília, Brazil.

Brazil. 2000. Regulamento Técnico de Identidade e Qualidade de Leite de Cabra. Instrução Normativa $\mathrm{n}^{\mathrm{o}} 37$, de 31 de Outubro. Ministério da Agricultura, Pecuária e Abastecimento, Brasília, Brazil.

Brazil. 2006. Regulamento Técnico sobre padrões microbiológicos para alimentos. Resolução RDC n⿳ำ 171, de 04 de setembro. Agência Nacional de Vigilância Sanitária, Brasília, Brazil. 
Cartoni, G. P., F. Coccioli, R. Jasionowska, and M. Masci. 1998. Determination of cow milk in buffalo milk and mozzarella cheese by capillary electrophoresis of the whey protein fractions. Ital. J. Food Sci. 2:127-131.

Carunchia Whetstine, M. E., Y. Karagul-Yuceer, Y. K. Avsar, and M. A. Drake. 2003. Identification and quantification of character aroma components in fresh Chevre-style goat cheese. J. Food Sci. 68:2441-2447.

Egito, A. S., G. M. S. Rosinha, L. E. Laguna, L. Miclo, J. M. Girardet, and J. L. Gaillard. 2006. Método eletroforético rápido para detecção da adulteração do leite caprino com leite bovino. Arq. Bras. Med. Vet. Zootec. 5:932-939.

FAOSTAT. 2011. Statistical basis. Accessed Nov. 10, 2013. http:// faostat3.fao.org/faostat-gateway/go/to/compare/Q/QC/S.

FarmPoint. 2013. Alagoas: Edital começa a selecionar cooperativas para fornecer leite de cabra e vaca. Accessed Dec. 20, 2013. http://www. farmpoint.com.br/cadeia-produtiva/giro-de-noticias/alagoasedital-comeca-a-selecionar-cooperativas-para-fornecer-leite-decabra-e-vaca-86765n.aspx.

Feligini, M., I. Bonizzi, V. C. Curik, P. Parma, G. F. Greppi, and G. Enne. 2005. Detection of adulteration in Italian mozzarella cheese using mitochondrial DNA templates as biomarkers. Food Technol. Biotechnol. 43:91-95.

Fisberg, M., M. Nogueira, A. Ferreira, and R. M. Fisberg. 1999. Aceitação e tolerância do leite de cabra em pré-escolares. Pediatr. Mod. $7: 526-530$.

Ha, J. K., and R. C. Lindsay. 1991. Contributions of cow, sheep, and goat milks to characterizing branched-chain fatty acid and phenolic flavors in varietal cheeses. J. Dairy Sci. 10:3267-3274.

Haenlein, G. F. W. 2004. Goat milk in human nutrition. Small Rumin. Res. 51:155-163.

Jirillo, F., E. Jirillo, and T. Magrone. 2010. Donkey's and goat's milk consumption and benefits to human health with special reference to the inflammatory status. Curr. Pharm. Des. 16:859-863.

Kaminarides, S. E., and E. M. Anifantakis. 1993. Comparative study of the separation of casein from bovine, ovine and caprine milks using HPLC. J. Dairy Res. 60:495-504

Law, A. J. R., and A. Tziboula. 1992. Quantitative fractionation of caprine casein by cation-exchange FPLC. Milchwissenschaft $47: 558-562$.
López-Calleja, I., I. González Alonso, V. Fajardo, M. A. Rodríguez, P. E. Hernández, T. García, and R. Martín. 2005. PCR detection of cow's milk in water buffalo milk and mozzarella cheese. Int. Dairy J. 15:1122-1129.

Mafra, I., A. Roxo, I. M. Ferreira, and M. B. Oliveira. 2007. A duplex polymerase chain reaction for the quantitative detection of cow's milk in goat's milk cheese. Int. Dairy J. 9:1132-1138.

Mašková, E., and I. Paulíčková. 2006. PCR-based detection of cow's milk in goat and sheep cheeses marketed in the Czech Republic. Czech J. Food Sci. 24:127-132.

Meilgaard, M. C., G. V. Civille, and B. T. Carr. 1991. Sensory Evaluation Techniques. 2nd ed. CRC Press, Boca Raton, FL.

Monteiro, A. A., A. C. D. S. Pires, and E. A. Araújo. 2011. Tecnologia de Produção de Derivados do Leite - Série Didática. 1st ed. Universidade Federal de Viçosa, Minas Gerais, Brazil.

Morgan, F., and P. Gaborit. 2001. The typical flavor of goat milk products: Technological aspects. Int. J. Dairy Technol. 54:38-40.

Park, Y. W., M. Juárez, M. Ramos, and G. F. W. Haenlein. 2007. Physico-chemical characteristics of goat and sheep milk. Small Rumin. Res. 68:88-113.

Queiroga, R. C. R. E., I. C. D. Guerra, E. V. Carlos, M. E. G. O. Oliveira, and E. L. Souza. 2009. Elaboração e caracterização físicoquímica, microbiológica e sensorial de queijo "tipo minas frescal" de leite de cabra condimentado. Revista Ciência Agronômica $3: 363-372$.

Roessler, E. B., R. M. Pangborn, J. L. Sidel, and H. Stone. 1978. Expanded statistical tables for estimating significance in pairedpreference, paired-difference, duo-trio and triangle tests. J. Food Sci. 43:940-944.

Santos, B. M., M. E. G. Oliveira, Y. R. F. Sousa, A. R. M. F. M. Madureira, M. M. E. Pintado, A. M. P. Gomes, E. L. Souza, and R. C. R. E. Queiroga. 2011. Caracterização físico-química e sensorial de queijo de coalho produzido com mistura de leite de cabra e de leite de vaca. Rev. Inst. Adolfo Lutz 3:302-310.

Skjevdal, T. 1979. Flavour of goat's milk. A review of studies on the sources of its variations. Livest. Prod. Sci. 6:397-405. 